\title{
Comparison of approaches for reporting forest fire-related biomass loss and greenhouse gas emissions in southern Europe
}

\author{
Maria Vincenza Chiriacò ${ }^{\mathrm{A}, \mathrm{D}}$, Lucia Perugini $^{\mathrm{A}}$, Dora Cimini $^{\mathrm{A}}$, Enrico D'Amato $^{\mathrm{B}}$, \\ Riccardo Valentini ${ }^{\mathrm{A}}$, Giovanni Bovio ${ }^{\mathrm{C}}$, Piermaria Corona ${ }^{\mathrm{A}}$ and Anna Barbati ${ }^{\mathrm{A}}$ \\ A University of Tuscia, Department for Innovation in Biological, Agro-food and Forest systems \\ (DIBAF), Via San Camillo de Lellis snc, I-01100 Viterbo, Italy. \\ ${ }^{B}$ Italian National Forest Service, Ispettorato Generale, Sistemi Informativi Automatizzati e \\ Telecomunicazioni (SIAT), Via Giosuè Carducci 5, I-00187 Rome, Italy. \\ C University of Turin, Department of Agronomy, Forest and Land Management, \\ Via L. da Vinci 44, I-10095 Grugliasco, Italy. \\ ${ }^{D}$ Corresponding author. Email: chiriaco@unitus.it
}

\begin{abstract}
Wildfires are the most common disturbances in Mediterranean forest ecosystems that cause significant emissions of greenhouse gases as a result of biomass burning. Despite this, there is reasonably high uncertainty regarding the actual fraction of burnt biomass and the related $\mathrm{CO}_{2}$ and non- $\mathrm{CO}_{2}$ gas emissions released during forest fires. The aim of this paper is to compare existing methodologies adopted in the National Greenhouse Gas Inventory reports of five of the most fire-affected countries of southern Europe (Italy, Spain, Greece, Portugal, France) with those proposed in the literature, to operationally estimate forest fire emissions, and to discuss current perspectives on reducing uncertainties in reporting activities for the Land Use, Land Use Change and Forestry sector under the United Nations Framework Convention on Climate Change and the Kyoto Protocol. Five selected approaches have been experimentally applied for the estimation of burnt biomass in forest fire events that occurred in Italy in the period 2008-2010. Approaches based on nominal rates of biomass loss can lead to an overly conservative value or, conversely, to underestimation of the fraction of burnt biomass. Uncertainties can be greatly reduced by an operational method able to assess inter-annual and local variability of fire effects on fire-affected forest types.
\end{abstract}

Additional keywords: $\mathrm{CO}_{2}$ and non- $\mathrm{CO}_{2}$ gases, fire intensity, fire severity, forest type.

Received 24 January 2012, accepted 1 January 2013, published online 13 May 2013

\section{Introduction}

Wildfires are the most common disturbance in Mediterranean forests (Schelhaas et al. 2003) causing significant emissions of greenhouse gases (GHGs) from forest biomass burning $\left(\mathrm{CO}_{2}\right.$, $\mathrm{CO}, \mathrm{CH}_{4}, \mathrm{~N}_{2} \mathrm{O}, \mathrm{NO}_{x}$ ). In the last 30 years (1980-2010), $\sim 50000$ forest fires occurred yearly in five of the most fire-affected countries of southern Europe (Portugal, Spain, France, Italy and Greece), burning yearly $\sim 0.5 \times 10^{6}$ ha. The annual forest burnt area, however, varies considerably depending on year-to-year climatological variability (European Commission 2011). When weather conditions are particularly severe (e.g. heat waves or very hot and dry summers combined with strong winds) forest fires may reach catastrophic proportions, the so-called megafires events, producing noteworthy GHG emissions in the atmosphere.

These extreme fire seasons usually receive world media coverage. Recent exceptional fire seasons occurred in Portugal ( 286000 ha of forest burnt in 2003 and 214000 ha in 2005), Spain (188 697 ha of forest burnt in 2005), Greece (193 268 ha of forests and other wooded land burnt in 2007), Italy (116 602 ha of forest burnt in 2007) and France (more than 70000 ha of forest burnt in 2003) (European Commission 2011). According to the European Forest Fire Information System (http:// forest.jrc.ec.europa.eu/effis/, accessed 22 February 2013) (San-Miguel-Ayanz et al. 2012), the $\mathrm{CO}_{2}$ emissions during recent catastrophic fires in Greece in 2007 were $\sim 4.5 \mathrm{Mt} \mathrm{CO}_{2}$ until the end of August, equalling $\sim 4 \%$ of the average annual $\mathrm{CO}_{2}$ emissions of this country. Emissions from wildfires in Portugal during the 2003 fire season were estimated to have reached 7.4 $\mathrm{Mt} \mathrm{CO}_{2}$ (Rosa et al. 2011).

Fire risk in Mediterranean forests is expected to further increase over the next 100 years, as climate change is likely to result in more extended hot periods and drought, with a summer temperature increase of $4-5^{\circ} \mathrm{C}$ and summer rainfall decrease of up to $50 \%$ through southern Europe (Lindner et al. 2010).

Estimates of GHG emissions from biomass burning can be highly uncertain, because of the high spatial and temporal variability of fuel loads, combustion completeness and seasonality 
of emissions composition (Keywood et al. 2011). The loss of forest biomass owing to burning is affected by fire intensity (i.e. the energy released during the fire) as well as by the structure and flammability of different fire-affected forest types and associated fuels (Xanthopoulos et al. 2012). For instance, ground-level wildfires are less intense, and their effect on trees less severe, than are crown fires. This variability in the level of damage, known as fire severity, makes fire effects on forest stands highly variable, ranging from fire-scarred trees to complete burning or uprooting (Schelhaas et al. 2003). Thus, as a consequence of a fire event, there is a fraction of living biomass (including understorey, leaves and small branches) that is destroyed and causes direct emissions of GHGs and a fraction that is transferred to the dead organic matter pool, which, if not removed by salvage logging operations will later decay, releasing indirect emissions.

Reporting on direct emissions from biomass burning within the forestry and agriculture sectors (the Land Use, Land Use Change and Forestry, LULUCF) is mandatory under the reporting requirements of both the United Nations Framework Convention on Climate Change (UNFCCC) and the Kyoto Protocol (KP). For this purpose, the Intergovernmental Panel on Climate Change (IPCC) has suggested methodologies to account for GHG emissions from biomass burning (Penman et al. 2003).

The extended formula to estimate $\mathrm{GHGs}\left(\mathrm{CO}_{2}\right.$ and non- $\left.\mathrm{CO}_{2}\right)$ directly released from fires is summarised by the following equation (Penman et al. 2003):

$$
L_{\text {fire }}=A \times B \times C \times D \times 10^{-6}
$$

where $L_{\text {fire }}$ is the amount of GHGs released as a result of fire (tonnes of GHG), $A$ is burnt area (ha), $B$ is mass of available fuel ( $\mathrm{kg}$ dry matter $\mathrm{ha}^{-1}$ ), $C$ is a combustion factor (fraction of the biomass combusted, dimensionless) and $D$ is an emission factor (g GHG kg-1 burnt fuel).

The burnt area $(A)$ is defined as the total forest surface affected by the fire. The mass of available fuel $(B)$ represents the existing total pre-disturbance biomass including surface and ground fuels. The combustion factor $(C)$ represents the fraction of pre-disturbance biomass that is actually combusted during the fire event (Ito and Penner 2004). The emissions factor $(D)$ defines the mass of released compounds of GHG per mass of dry fuel burnt (Andreae and Merlet 2001).

The combustion factor $(C)$ is the most critical term in the estimation of GHG emissions. $\mathrm{CO}_{2}$ emissions released as a result of forest fires are calculated in relation to the carbon released during fires, which is assumed to equal $50 \%$ of the biomass loss (Penman et al. 2003). Furthermore, this calculation affects non- $\mathrm{CO}_{2}$ GHG emissions estimates. Unless countryspecific factors are available, non- $\mathrm{CO}_{2}$ emissions are calculated by multiplying the total carbon released during fires by default emission factors $\left(0.012\right.$ for $\mathrm{CH}_{4} ; 0.06$ for $\mathrm{CO} ; 0.007$ for $\mathrm{N}_{2} \mathrm{O}$; 0.121 for $\mathrm{NO}_{x}$ ) provided by Penman et al. (2003).

Three hierarchical tiers of methods to assess GHG emissions are proposed by Penman et al. (2003) and these range from default data and simple equations to the use of country-specific data and models to accommodate national circumstances. Tiers progress from low (Tier 1) to high (Tier 3) levels of certainty in estimates. It is recommended that national inventories reduce uncertainty as far as possible and increase accuracy by implementing the higher tiers of methods where possible.

It is clear that an accurate assessment of $\mathrm{CO}_{2}$ emissions from forest fires is of strategic importance for reporting on emissions for the LULUCF sector, especially in the most fire-affected countries of southern Europe. This paper aims to highlight this issue by addressing the following goals:

(i) review and compare existing approaches to estimate forest biomass loss and related GHG emissions in the five most fire-affected countries of southern Europe;

(ii) apply the existing approaches for biomass loss assessment to a country-wide case study, i.e. the estimation of forest biomass loss in forest fire events that occurred in Italy in the period 2008-2010;

(iii) discuss current perspectives on reducing uncertainty in the estimates of GHG emissions from forest fires in the framework of UNFCCC and KP reporting activities for the LULUCF sector.

\section{Review of reporting on forest-fire related GHG emissions}

The national GHG inventory reports (NIRs) annually produced by the five most fire-affected southern European countries under the UNFCCC and the KP were analysed and compared in line with IPCC guidelines. Furthermore, pertinent literature was reviewed in order to identify other methods applicable to the assessment of forest biomass loss from forest fires.

The accuracy of the forest fire data consistently available at country level clearly constrains the choice of the method applicable for assessing GHG emissions from forest fires. For Italy, Portugal and Greece estimation of the annual burnt forest area $(A)$ is possible, with a reasonable level of accuracy, because the forest fire perimeters are available as country-wide geodatasets derived from GPS survey or remote sensing. Conversely in Spain and France only some regions have burnt areas geodatasets (Table 1). The annual burnt forest area does not include areas treated by prescribed burning in countries where this technique is applied (Portugal, France and northern Spain). Prescribed burning cannot be considered a wildfire, being based on the use of low-intensity fires to reduce fuel loads under specified controlled fuel and weather conditions. As such, emissions from prescribed burning can be regarded as negligible, because the related combustion factors are much lower than in wildfires.

The existing pre-disturbance mass of available fuel $(B)$ can be reliably estimated by applying national forest inventory data (growing stock, living biomass expansion factors) to the burnt area stratified into the main forest vegetation types.

In southern European countries different approaches are applied for the estimation of the combustion factor $(C)$ (Table 2). Spain and Italy calculate $\mathrm{CO}_{2}$ emissions from forest fires assuming the complete oxidation of the aboveground biomass at the time of fire (ES NIR 2011; IT NIR 2011). These countries adopt a conservative approach based on the assumption that the whole biomass is completely oxidised and that the total related carbon is immediately released into the atmosphere during the 

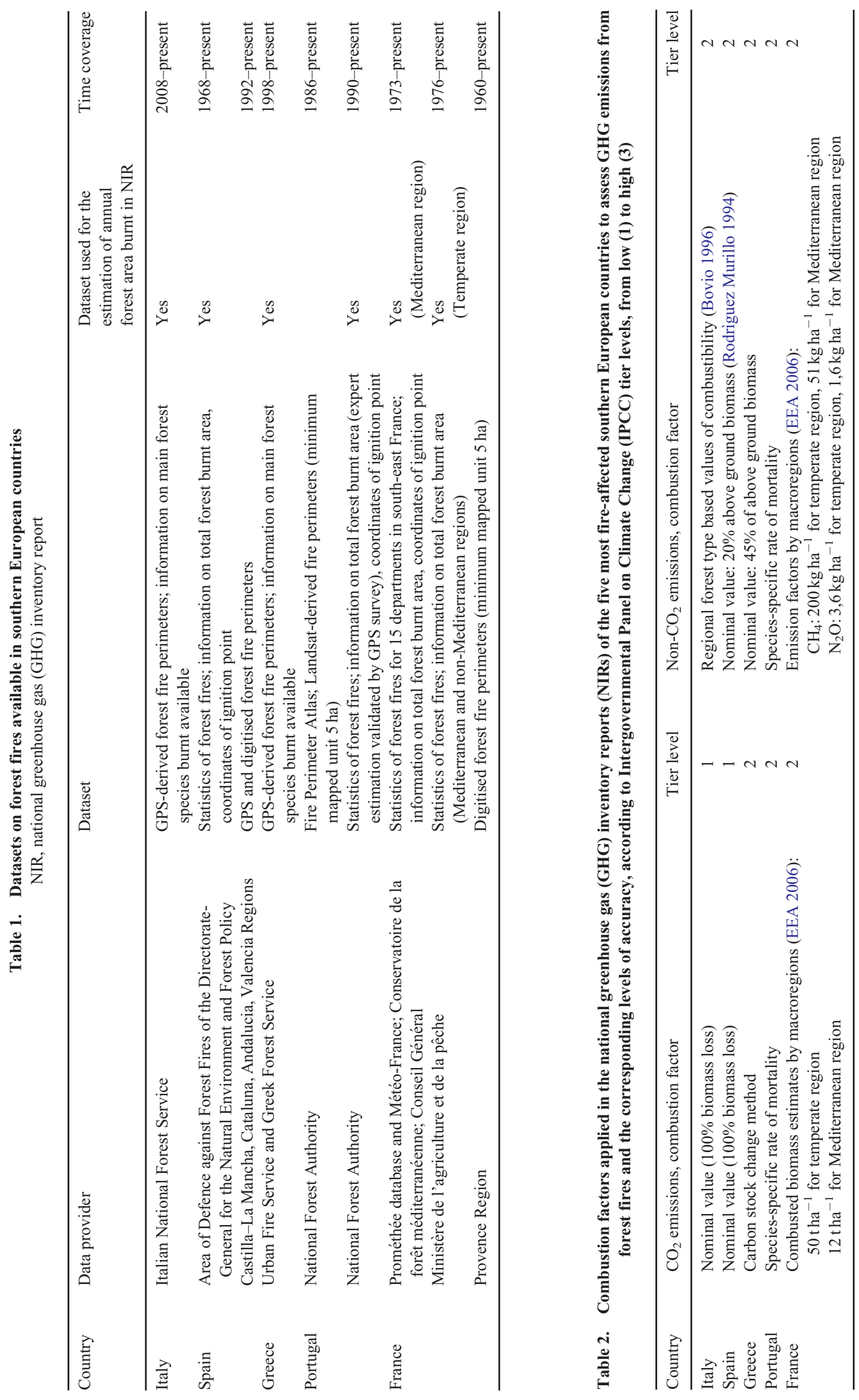
Table 3. Combustible biomass values (Bovio 1996) adopted in Italian NIR for calculating the amount of carbon released during the fire for non- $\mathrm{CO}_{2}$ emissions assessment

1st group: Piedmont, Aosta Valley, Lombardy, Trentino-Alto Adige, FriuliVenezia Giulia, Veneto, Emilia-Romagna; 2nd group: Liguria, Tuscany, Marche, Umbria, Lazio, Abruzzo, Molise; 3rd group: Campania, Apulia, Basilicata, Calabria, Sicily, Sardinia

\begin{tabular}{lccc}
\hline Forest physiognomy & \multicolumn{3}{c}{ Combustible biomass $\left(\mathrm{t} \mathrm{ha}^{-1}\right)$} \\
& 1st group & 2nd group & 3rd group \\
\hline Coppice & $7-9$ & $7-9$ & $7-9$ \\
Coppice with standards & $7-9$ & $7-9$ & $7-9$ \\
Degraded coppice & $5-8$ & $10-15$ & $10-15$ \\
High coniferous forest & $10-12$ & $7-9$ & $7-9$ \\
High broadleaved forest & $10-12$ & $10-12$ & $7-9$ \\
Mix high forest & $10-15$ & $7-9$ & $7-9$ \\
Non-forested & $5-10$ & $10-15$ & $25-35$ \\
\hline
\end{tabular}

forest fire. The resulting nominal rate of total burnt biomass $(100 \%)$ falls in the lowest level of accuracy (Tier 1) as defined by Penman et al. (2003) who consider forest fires as standreplacing disturbances. It clearly produces an overestimation of direct emissions as some trees could survive after fire or some partially burnt fuel may remain on the site as charcoal or be transferred to the dead organic matter pool. Moreover, a fraction of fire-damaged biomass could be recovered after the fire and used as timber or firewood, depending on the condition of trees after the fire event has taken place. In this case, the risk of double counting of emissions increases if this amount of biomass and the related carbon emissions is also calculated as harvesting or transferred to harvested wood products, which will be included in the accounting of the LULUCF sector in the post-2012 agreement (UNFCCC 2011).

Spain and Italy assess the carbon released for calculating non- $\mathrm{CO}_{2}$ emissions using different approaches from the nominal $100 \%$ rate. Spain assumes the fraction of burnt biomass to be $20 \%$ of aboveground biomass; this oxidised carbon constitutes 'prompt' emissions (Rodrìguez Murillo 1994). This nominal approach is based on the assumption that only a small fraction of aboveground biomass is burnt and most of the fire-affected trees remain on the soil as dead organic matter or charcoal. Italy calculates the non- $\mathrm{CO}_{2}$ emissions during forest fires on the basis of regional parameters of combustible biomass derived by Bovio (1996), from the implementation of a United States fuel model (Anderson 1982). The values of combustible biomass are defined considering different management systems and three groups of Italian regions that are relatively homogeneous in terms of forest vegetation types (Table 3).

Greece estimates emissions and removals from managed forests in the LULUCF sector by means of the carbon stock change method (GR NIR 2011) based on the difference between two biomass stock inventories at two different points in time. For this reason no extra emissions of $\mathrm{CO}_{2}$ from forest fires are reported as the method quantifies the net biomass change without differentiating the causes of loss. However, the biomass burnt annually in managed forests is estimated in order to assess non- $\mathrm{CO}_{2}$ emissions. The total carbon released during fires is calculated by multiplying the forest burnt areas by the average biomass stock of forest areas (per forest type) excluding the fraction of biomass transferred to dead organic matter. It must be observed that the latter term is assessed by applying default values provided by Penman et al. (2003) under Tier 1, i.e. 0.55 for forests and 0.28 for scrublands. Consequently, it can be assumed that $45 \%$ of the carbon content of aboveground living biomass in burnt forests is directly released to the atmosphere and the remaining $55 \%$ is transferred to dead organic matter.

In its last NIR (PT NIR 2011), Portugal attempted to assess biomass loss with a high degree of accuracy taking into account the possible double counting related to salvage logging. Biomass loss was assessed for the main Portuguese species (Pinus pinaster Ait., P. pinea L., Quercus suber L., Q. rotundifolia Lam., Quercus spp., Eucalyptus spp., other coniferous and other broadleaves) by applying rates of mortality derived from a literature review. Biomass loss owing to mortality was further discounted by an assumed fraction of fire-damaged biomass removed after fire by salvage logging, as judged by a panel of national experts. The methodology adopted by Portugal also took into account, according to the mortality rate, the portion of belowground biomass affected by fire by multiplying the burnt aboveground biomass by the root: shoot ratio.

In estimating $\mathrm{CO}_{2}$ emissions from wildfires France differentiates fires occurring in its Mediterranean region from those occurring in the temperate region (FR NIR 2011). Although the Mediterranean region of France is more subject to forest fires than is the rest of the French territory, it is characterised by a lower forest biomass. For this reason, GHG emissions in these two regions are estimated separately, using specific combustion factors reflecting differences in vegetation type and growing stock levels (EEA 2006).

Besides the approaches applied in the NIRs, a few operational methodologies to estimate GHG emissions from forest fires are also available in the literature. Lazaridis et al. (2008) propose that for the assessment of fire emissions in Greece the fraction of aboveground biomass combusted should be assumed to be in the order of $28 \mathrm{t} \mathrm{ha}^{-1}$ for Mediterranean forests, $24 \mathrm{tha}^{-1}$ for scrubland and $3.6 \mathrm{t} \mathrm{ha}^{-1}$ for grassland; all values derived by Seiler and Crutzen (1980) and EEA (2002). Rosa et al. (2011) developed a methodology to estimate annual emissions from forest fires in Portugal based on the fire perimeter atlas derived from Landsat satellite imagery (Pereira and Santos 2003) and biomass fuel loadings differentiated by forest type and fuel stratum (litter, shrubs, leaves and fine branches). The authors argued that woody fuels $>2 \mathrm{~cm}$ are not consumed by fires unless events of extreme severity occur. Combustion factors for other fuel strata were based on a literature review and were estimated to be higher than $50 \%$.

Bovio (2007) has developed an approach to assess forest fire damage and related biomass loss in Italy. The approach is based on the consideration that the level of damage owing to forest fires corresponds to the amount of burnt biomass, which depends on two main factors: the intensity of the fire and the type of forest vegetation affected by fire. A fire of a given intensity can produce different levels of damage depending on the fuelbed strata that are burnt (tree canopy, shrub, low vegetation, woody fuel, litter fuel) and their flammability (Xanthopoulos et al. 2012). These characteristics show high 
Table 4. Groups of forest vegetation classes homogeneous with respect to response to fire in Italy (Bovio 2007)

\begin{tabular}{ll}
\hline Forest vegetation & Physiognomical characterisation \\
class & \\
\hline A & Maple-ash forests \\
& Hygrophilous riparian forests \\
& Lowland oak high forests \\
& Beech high forests \\
& Birch high forests \\
& Evergreen oak high forests \\
& Downy oak and Turkey oak high forests \\
B & Larch and larch-arolla pine forests \\
& Spruce forests \\
C & Fir forests \\
& Mixed fir and spruce forests \\
& Mountain Scots pine forests \\
& Mountain black pine forests \\
& Hilly and flatlands Scots pine forests \\
& Other conifer forests \\
& Mediterranean pine forests \\
I & Calabrian and palebark pine forests and hilly \\
black pine forests & Beech coppices \\
& Chestnut coppices \\
& Common hornbeam coppices \\
& Sessile oak and downy oak coppices \\
& European hophornbeam coppices \\
& Evergreen oak coppices \\
& Mediterranean maquis \\
&
\end{tabular}

variability across different forest ecosystems, though relatively homogeneous groups have been identified for main forest vegetation classes in Italy (Table 4). Therefore, the approach uses information that can be assessed easily in burnt areas after the fire: the dominant pre-fire forest type and scorch height represent proxy variables of fire intensity to assess the fraction of biomass burnt in a fire event (Table 5). This method has been recently proposed for the inventory of Italian emissions from forest fires (IEIF) in the framework of the Italian National Registry for Forest Carbon Sinks (IT NIR 2011).

\section{Comparison of approaches for assessing biomass loss}

The annual burnt forest area in Italy ranged from 19357 to 31060 ha year $^{-1}$ in the period 2008-2010, according to fire perimeters geodatasets provided by the Italian National Forest Service (Corpo Forestale dello Stato, see http://www3. corpoforestale.it/flex/cm/pages/ServeBLOB.php/L/IT/IDPagina/ 6358, accessed 22 February 2013). This geographical dataset allows the assessment of the fraction of forest burnt biomass according to the abovementioned approaches. Total burnt area for each year can be divided into several types of burnt forest vegetation, classified according to the Italian national forest inventory (INFC 2005) classes, which can be easily linked to the forest vegetation classes presented in Tables 3 and 4 . In addition, scorch height information is available for all fire events in the dataset.

The forest fires that occurred in Italy in the period 2008-2010 were considered as a case study to compare the fraction of burnt biomass using different methods. The annual burnt forest area (A) was assessed from the available country-wide geodataset of the forest fire perimeters, derived from GPS survey. The existing pre-fire biomass values $(B)$ were calculated for all approaches only for the aboveground living biomass pool and were derived from average standing volume data reported by INFC (2005) per forest type, and 20 Italian administrative regions. Wood volume was converted into forest biomass using wood basal densities and expansion factors applied in the Italian NIR (IT NIR 2011).

Five approaches were compared and biomass loss values were calculated as follows.

\section{Approach. 1: 100\% of biomass loss}

This is the nominal approach currently applied by Italy and Spain in the NIR to estimate $\mathrm{CO}_{2}$ emissions from forest fires, where biomass loss is assessed multiplying the burnt forest area (according to administrative region and forest vegetation class as in Table 4) by the regional values of forest biomass derived from INFC (2005) on a forest type basis.

\section{Approach 2: $20 \%$ of biomass loss}

This approach was based on the assumed fraction of burnt biomass applied in the Spanish NIR (ES NIR 2011) to estimate non- $\mathrm{CO}_{2}$ emissions; biomass loss was assessed by multiplying by 0.20 the values provided by Approach 1 .

\section{Approach 3: biomass loss values per forest type}

This approach used the assumed fraction of burnt biomass applied in the Italian NIR (IT NIR 2011) to estimate non- $\mathrm{CO}_{2}$ emissions. Biomass loss was assessed multiplying the burnt forest area, classified per forest physiognomy and geographical distribution, by the combustible biomass values reported in Table 3.

\section{Approach 4: level of damage}

Approach 4 followed the method developed by Bovio (2007) to assess forest fires damage. The fraction of biomass burnt by forest fires was calculated by multiplying the burnt forest area, according to administrative region and forest vegetation class (Table 4), by the damage level score assessed on the basis of forest vegetation class and scorch height (Table 5).

\section{Approach 5: mortality rate and salvage logging}

The last approach followed the methodology adopted by Portugal in the last NIR (PT NIR 2011); the approach is applicable only to a limited extent in Italy as mortality rates were defined for the main Portuguese forest species and are applicable only to a few Italian forest vegetation classes (Table 6). In order to assess the biomass loss owing to forest fires, the most conservative rates of mortality and of salvaged deadwood in total burnt wood provided in the Portuguese NIR (PT NIR 2011) were applied. 
For the application of Approaches 4 and 5, the INFC (2005) forest types detected in burnt surfaces were matched respectively with the combustible biomass values (Bovio 1996) and forest vegetation classes identified by Bovio (2007). 'Temporarily not wooded lands' were not taken into account. The biomass value

Table 5. Level of fire damage (expressed as biomass loss percentage) experienced by each forest vegetation class (Bovio 2007), at different fire intensities

NR, not recorded

\begin{tabular}{lccccc}
\hline $\begin{array}{l}\text { Forest vegetation } \\
\text { class }\end{array}$ & \multicolumn{5}{c}{$\begin{array}{c}\text { Scorch height (m) } \\
\end{array}$} \\
& $<1$ & $1-2.5$ & $\begin{array}{c}2.5-3.5 \\
\text { Intensity }\left(\mathrm{kW} \mathrm{m}^{-1}\right)\end{array}$ \\
& $<350$ & $350-1700$ & $1701-3500$ & $3501-7000$ & $>7000$ \\
\hline A & 0.10 & 0.15 & 0.30 & 0.60 & NR \\
B & 0.08 & 0.20 & 0.30 & 0.80 & 0.90 \\
C & 0.10 & 0.25 & 0.50 & 0.80 & 0.90 \\
D & 0.08 & 0.30 & 0.55 & 0.85 & 0.95 \\
E & 0.05 & 0.15 & 0.40 & 0.65 & NR \\
F & 0.05 & 0.20 & 0.35 & 0.60 & 0.95 \\
G & 0.10 & 0.30 & 0.60 & 0.80 & 0.95 \\
H & 0.30 & 0.70 & 0.80 & 0.90 & 1.00 \\
I & 0.25 & 0.40 & 0.70 & NR & NR \\
\hline
\end{tabular}

for the Mediterranean maquis ( $50 \mathrm{t}$ dry matter $\mathrm{ha}^{-1}$ ) was derived from the average data for coppice of evergreen broadleaves from the INFC (2005) and from a literature review of the main Italian publications dealing with the issue (Gratani et al. 1980; Bianchi et al. 2002; Ciancio and Nocentini 2002; Costa and La Mantia 2005).

In this exercise only the burnt aboveground biomass fraction was assessed. The decision to include also the belowground carbon pool in the emissions from forest fires should be taken with caution and carefully evaluated depending on fire intensity and the management system (coppice or high forest). In the case of coppices, if the fire is not so intense as to hamper the stump sprouting ability, the root systems retain their function and no emissions should be reported. On the contrary, in the case of coniferous forest, if the fire destroys the aboveground part of the tree, then the stump will not have the ability to re-sprout and will die unless root anastomosis occurs. The biomass of dead root systems should be considered transferred to the soil organic matter and emissions from its decay should be estimated on a decadal time scale.

\section{Results}

The results from the five approaches are presented in Table 7, in terms of unitary biomass loss values estimated for the burnt

Table 6. Rate of mortality and percentage of salvage wood out of total burnt wood for the main Portuguese forest species (PT NIR 2011) matched with the three corresponding forest vegetation classes identified by Bovio (2007)

\begin{tabular}{|c|c|c|c|c|}
\hline Forest vegetation class & Scientific name & Common name & Rate of mortality (\%) & Salvage wood (\%) \\
\hline \multirow[t]{12}{*}{ A } & Eucalyptus spp. & & & \\
\hline & E. globulus & Tasmanian blue gum & 50 & 40 \\
\hline & E. camaldulensis & Red gum & & \\
\hline & Eucalyptus spp. & Other gums & & \\
\hline & Other broadleaves & & & \\
\hline & Acacia spp. & Acacias & & \\
\hline & Arbutus unedo & Strawberry tree & & \\
\hline & Betula spp. & All Birches & & \\
\hline & Castanea sativa & Sweet chestnut & & \\
\hline & Ceratonia siliqua & Carob tree & & \\
\hline & Salix spp. & Willows & & \\
\hline & Ulmus spp. & Elms & & \\
\hline \multirow[t]{7}{*}{ B } & Quercus spp. & & & \\
\hline & Q. suber & Cork oak & 30 & 40 \\
\hline & Q. rotundifolia & Holm oak & & \\
\hline & Q. faginea & Portuguese oak & & \\
\hline & Q. pyrenaica & Pyrenean oak & & \\
\hline & Q. robur & Pedunculate oak & & \\
\hline & & Other oaks & & \\
\hline \multirow[t]{9}{*}{$\mathrm{D}$} & Pinus spp. & & & \\
\hline & P. pinaster & Maritime pine & 70 & 40 \\
\hline & P. pinea & Umbrella pine & & \\
\hline & & Other pines & & \\
\hline & Other coniferous & & & \\
\hline & Cupressus spp. & Cypresses & & \\
\hline & Pinus halepensis & Aleppo pine & & \\
\hline & Pinus sylvestris & Scots pine & & \\
\hline & Pseudotsuga menziesii & Douglas-fir & & \\
\hline
\end{tabular}


Table 7. Average aboveground biomass loss per hectare of burnt forest area in Italy estimated using the different approaches Approach 1, 100\% of biomass loss; Approach 2, 20\% of biomass loss; Approach 3, biomass loss values per forest type; Approach 4, level of damage; Approach 5, mortality rate and salvage logging

\begin{tabular}{|c|c|c|c|c|c|c|c|c|c|c|c|c|c|c|c|}
\hline \multirow{3}{*}{$\begin{array}{l}\text { Forest vegetation } \\
\text { class }\end{array}$} & \multicolumn{3}{|c|}{ Approach 1} & \multicolumn{3}{|c|}{ Approach 2} & \multicolumn{3}{|c|}{ Approach 3} & \multicolumn{3}{|c|}{ Approach 4} & \multicolumn{3}{|c|}{ Approach 5} \\
\hline & 2008 & 2009 & 2010 & 2008 & 2009 & 2010 & 2008 & 2009 & 2010 & 2008 & 2009 & 2010 & 2008 & 2009 & 2010 \\
\hline & \multicolumn{15}{|c|}{ Biomass loss $\left(\mathrm{tha}^{-1}\right)$} \\
\hline A & 154 & 179 & 141 & 31 & 36 & 28 & 10 & 10 & 10 & 24 & 31 & 25 & 46 & 40 & 12 \\
\hline B & 134 & 122 & 76 & 27 & 24 & 15 & 9 & 10 & 10 & 26 & 42 & 13 & 24 & 10 & 5 \\
\hline $\mathrm{C}$ & 76 & 138 & 86 & 15 & 28 & 17 & 11 & 10 & 10 & 9 & 64 & 30 & - & - & - \\
\hline $\mathrm{D}$ & 148 & 166 & 139 & 30 & 33 & 28 & 9 & 9 & 9 & 27 & 124 & 78 & 62 & 43 & 22 \\
\hline E & 123 & 118 & 150 & 25 & 24 & 30 & 14 & 15 & 12 & 21 & 28 & 10 & - & - & - \\
\hline $\mathrm{F}$ & 58 & 64 & 65 & 12 & 13 & 13 & 15 & 15 & 15 & 7 & 12 & 14 & - & - & - \\
\hline G & 50 & 50 & 50 & 10 & 10 & 10 & 31 & 29 & 26 & 10 & 18 & 15 & - & - & - \\
\hline Average & 104 & 116 & 88 & 21 & 23 & 18 & 16 & 16 & 17 & 17 & 40 & 27 & - & - & - \\
\hline
\end{tabular}

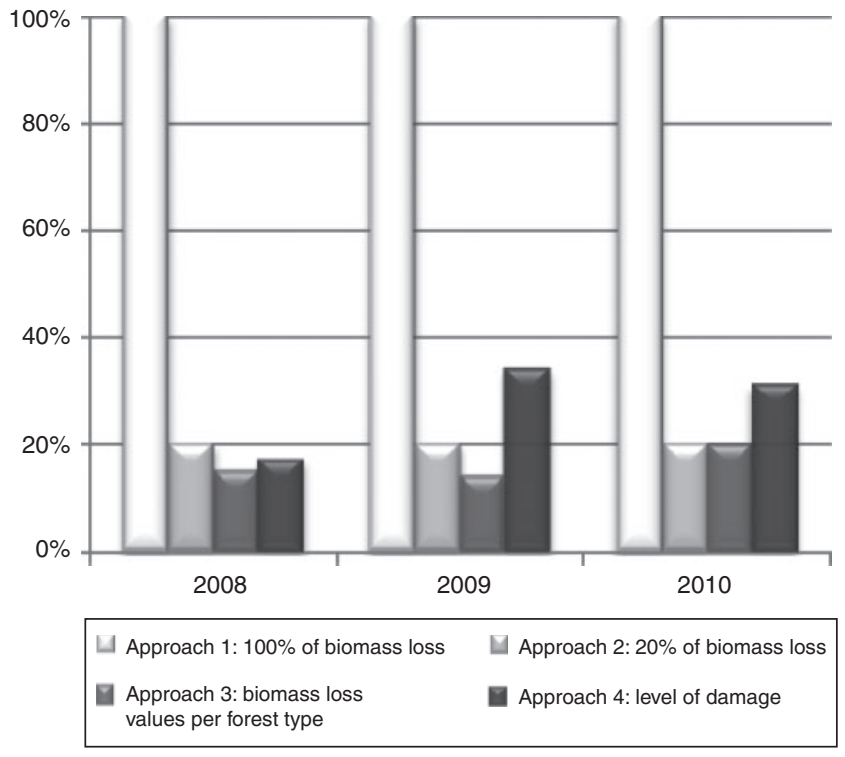

Fig. 1. Comparison of yearly estimates of total biomass loss (\%) from forest fires in Italy, as quantified by Approaches 1 to 4 (see text). Approach 5 is not included as it can be applied only to a few vegetation classes (see Table 6).

forest areas of different forest types in Italy for the years 20082010. Total yearly values of forest biomass loss range between 14 (Approach 3; 2009) and 34\% (Approach 4; 2009) of the total standing biomass, against the nominal value of $100 \%$ (Fig. 1). The range of variation of forest biomass loss further increases when considering single forest vegetation classes (Table 8).

Inter-annual variation in unitary biomass loss values provided by each approach for the different vegetation classes (Table 7) can be attributed to the variability in the relative share of fireaffected forest areas across regions, affecting the local values of biomass loss. Differences between the outcomes of Approaches 3 and 5 within the same year and forest vegetation class are a result of differences in the assumed values of biomass loss, mostly determined on the basis of the 'average' fire response of the forest type. The most pronounced differences in unitary
Table 8. Range of biomass loss in Italy during 2008-2010 by forest vegetation class estimated by different approaches

Biomass loss percentage of $100 \%$ under Approach 1 is excluded. Different approaches used for estimation are indicated in parentheses (numbers defined in Table 7)

\begin{tabular}{lcc}
\hline Forest vegetation class & \multicolumn{2}{c}{ Biomass loss range (\%) } \\
& Minimum & Maximum \\
\hline A & $5(3,5)$ & $30(5)$ \\
B & $6(5)$ & $34(4)$ \\
C & $7(3)$ & $46(4)$ \\
D & $5(3)$ & $74(4)$ \\
E & $7(4)$ & $24(4)$ \\
F & $11(4)$ & $25(3)$ \\
G & $20(2)$ & $62(3)$ \\
\hline
\end{tabular}

biomass loss values (provided by Approach 4) are mostly linked to inter-annual variability of fire diffusion levels.

Overall, the highest biomass loss values were provided by Approach 4 in all years and for most forest vegetation classes, except for oak coppices (F) and Mediterranean maquis (G), for which Approach 3 assumes higher losses.

Looking at the range of values found for the different vegetation classes (Table 8), estimates from Approach 2 are always in the range of variation of biomass loss values provided by other methods.

\section{Discussion}

The five most fire-affected countries of southern Europe adopt different methods for accounting GHG emissions from forest fires, with either Tier 1 or Tier 2 levels of certainty.

The comparison between different approaches carried out with a country-wide case study in Italy helps in finding a more realistic range of variation of biomass loss than the nominal approach assuming $100 \%$ of biomass loss (Approach 1; currently applied by Italy and Spain for estimating $\mathrm{CO}_{2}$ emissions for Kyoto Protocol reporting), which clearly results in an overly conservative value for all forest types. The approach assuming a nominal rate of $20 \%$ of biomass loss (Approach 2), assigned 
independently from the fire event characteristics (e.g. affected forest type, fire intensity), appears to be a fairly low nominal estimate, at least for the most fire-affected Mediterranean forest types (B, D, E). Thus, the application of the $20 \%$ nominal rate could lead to an underestimation of biomass loss values in fireprone Mediterranean forest types, especially during extreme fire seasons. Uncertainties in the estimates can be reduced by the other three approaches, more consistent with the fire behaviour of the fire-affected forest types.

Except for a couple of forest vegetation classes, the approach applying biomass loss values per forest type (Approach 3) provides a less conservative estimate than using the level of damage (Approach 4), resulting in lower values of biomass loss for all the years investigated. Furthermore, the data on combustible biomass required by the approach based on biomass loss values per forest type (Approach 3) are easy to obtain, although the combustible biomass values are derived from United States models (Anderson 1982), which might not be strictly applicable to the Mediterranean context.

The approach using mortality rate and salvage logging information (Approach 5) adopted by Portugal (PT NIR 2011) provides an assessment at relatively high level of accuracy as biomass loss rates are defined on the basis of country-level estimates of species-specific mortality and salvage logging rates. A higher accuracy can be reached if the values of salvaged wood, currently defined by expert judgment, are assigned via an ad hoc statistical system. However, Approach 5 is not easily applicable to all Mediterranean environments because mortality rates are country-specific and provided only for a small group of forest species. To be applied in other countries, detailed mortality rates per species, or at least per main forest type, should be developed at the national level.

The level of damage approach (Approach 4) provides an assessment of biomass loss that explicitly takes into account spatiotemporal variability in biomass loss from forest fires. Uncertainties in the estimation of the fraction of burnt biomass are greatly reduced by this approach, as the variability in the level of damage (fire severity) in different forest types is directly assessed in the field. This requires a more demanding operational effort in collecting the specific fire data needed to estimate fire damage (i.e. a scorch height assessment). In Italy these data have been collected and stored in the geodatasets of forest fires perimeters only since very recently. From a methodological viewpoint, Approach 4 seems to be the most promising for fulfilling the requirement for a higher level of accuracy, proposed as tier levels by Penman et al. (2003), to estimate GHG emissions from forest fires. Biomass loss assessment is based, in fact, on detected effects of forest fires, i.e. scorch height assessment; such information, theoretically, could be collected easily in those southern European countries that perform postfire field survey mapping through GPS.

This approach would greatly reduce uncertainties owing to spatiotemporal variability in biomass burning, an aspect extremely relevant especially when estimating emissions from large intense fires, such as mega-fires. In contrast, in the context of Kyoto accounting rules, when no accurate fire data are available at a national level, the more conservative estimate is favoured. Thus, assuming $100 \%$ of biomass loss still represents a widely used approach, because it leads to an overestimation of emissions in the sector, hence avoiding the risk of a country accounting undue credits.

\section{Acknowledgements}

This research was developed within the agreement (2010-2011) between the Italian Ministry for Environment, Territory and Sea and the Department for Innovation in Biological, Agro-food and Forest systems (formerly DISAFRI) for the scientific support to the National Registry for Forest Carbon Sinks. A. Barbati and P. Corona participated also under the scope of research project 'FUME - Forest fires under climate, social and economic changes in Europe, the Mediterranean and other fire-affected areas of the world', European Commission FP7-ENV-2009, Grant Agreement Number 243888. We thank P. Canaveira, T. Curt, G. De Las Heras, C. Garcia Diaz, J. M. C. Pereira and G. Xanthopolous for their contribution in revising the paper. We thank also the two anonymous reviewers for their helpful suggestions on earlier drafts of this paper.

\section{References}

Anderson HE (1982) Aids to determining fuel models for estimating fire behavior. USDA Forest Service, Intermountain Forest and Range Experiment Station, General Technical Report INT-GTR-122. (Ogden, UT)

Andreae MO, Merlet P (2001) Emission of trace gases and aerosols from biomass burning. Global Biogeochemical Cycles 15(4), 955-966. doi:10.1029/2000GB001382

Bianchi L, Calamini G, Gregori E, Paci M, Pallanza S, Pierguidi A, Salbitano F, Tani A, Vedele S (2002) Valutazione degli effetti del rimboschimento in zone aride della Sardegna: risultati preliminari sulla vegetazione. L'Italia forestale e montana 4, 353-368.

Bovio G (1996) Stima della biomassa bruciata e della $\mathrm{CO}_{2}$ prodotta da incendi boschivi in Italia. Schweizerische Zeitschrift fuer Forstwesen 147(4), 281-292.

Bovio G (2007) Method for forest fire damage level assessment based on detectable effects. In 'Evaluation of Forest Fire Damages in Italy'. (Eds O Ciancio, P Corona, M Marinelli, D Pettenella) pp. 55-60. (Accademia Italiana di Scienze Forestali: Florence, Italy)

Ciancio O, Nocentini S (Eds) (2002) 'Il Bosco Ceduo in Italia.' (Accademia Italiana di Scienze Forestali: Florence, Italy)

Costa G, La Mantia T (2005) Il ruolo della macchia mediterranea nel sequestro del carbonio. Forest@ 2(4), 378-387. doi:10.3832 EFOR0319-0020378

EEA (2002) EMEP/CORINAIR Atmospheric Emission Inventory Guidebook, 3rd edn. EMEP Task Force on Emission Inventories, Technical Report Number 30. Available at http://www.eea.europa.eu/publications/ technical_report_2001_3 [Verified 22 February 2013]

EEA (2006) EMEP/CORINAIR Atmospheric Emission Inventory Guidebook - 2006. Technical Report Number 11/2006. Available at http://www.eea.europa.eu/publications/EMEPCORINAIR4 [Verified 22 February 2013]

ES NIR (2011) Inventario de emisiones de gases de efecto invernadero de España e información adicional años 1990-2009. Ministerio de Medio Ambiente y Medio Rural y Marino, Comunicación a la secretaría del Convenio marco sobre cambio climático y Protocolo de Kioto, Abril de 2011. Available at http://unfccc.int/files/national_reports/annex_i_ghg inventories/national_inventories_submissions/application/zip/esp-2011nir-14apr.zip [Verified 22 February 2013]

European Commission (2011) Forest Fires in Europe 2010. Joint Research Centre, Institute for Environment and Sustainability, JRC Scientific and Technical Reports Number 11. Available at http://publications.jrc.ec. europa.eu/repository/bitstream/111111111/22337/2/firereport2010_ final_toprint.pdf [Verified 22 February 2013]

FR NIR (2011) Rapport National d'inventaire pour la France au titre de la convention Cadre des Nations Unies sur les Changements Climatiques et du Protocole de Kyoto. Centre Interprofessionnel Technique d'Etudes de 
la Pollution Atmosphérique (CITEPA), Mars 2011. (Paris) Available at http://unfccc.int/files/national_reports/annex_i_ghg_inventories/national_ inventories_submissions/application/zip/fra-2011-nir-11apr.zip [Verified 22 February 2013]

GR NIR (2011) Emissions inventory - annual inventory submission under the Convention and the Kyoto Protocol for greenhouse and other gases for the years 1990-2009. Ministry of Environment, Energy and Climate Change, April 2011. (Athens) Available at http://unfecc.int/files/national_ reports/annex_i_ghg_inventories/national_inventories_submissions/ application/zip/grc-2011-nir-15apr.zip [Verified 5 April 2013]

Gratani L, Amadori M, Veri L, Bruno F, Porri M (1980) Determinazione di un metodo di stima della Biomassa della macchia di Castelporziano (Lazio). Annals of Botany 41(1), 131-151.

INFC (2005) Inventario Nazionale delle Foreste e dei Serbatoi Forestali di Carbonio. Ministero delle Politiche Agricole Alimentari e Forestali, Ispettorato Generale - Corpo Forestale dello Stato (CRA) - Unità di ricerca per il Monitoraggio e la Pianificazione forestale. Available at http://www.sian.it/inventarioforestale/jsp/dati_carquant_tab.jsp [Verified 22 February 2013]

IT NIR (2011) Italian Greenhouse Gas Inventory 1990-2009. Institute for Environmental Protection and Research (ISPRA), National Inventory Report, April 2011. (Rome) Available at http://unfecc.int/files/national_ reports/annex_i_ghg_inventories/national_inventories_submissions/ application/zip/ita-2011-nir-15apr.zip [Verified 22 February 2013]

Ito A, Penner JE (2004) Global estimates of biomass burning based on satellite imagery for the year. Journal of Geophysical Research 109, D14S05. doi:10.1029/2003JD004423

Keywood M, Kanakidou M, Stohl A, Dentener F, Grassi G, Meyer CP, Torseth K, Edwards D, Thompson AM, Lohmann U, Burrows J (2011) Fire in the air - biomass burning impacts in a changing climate. Critical Reviews in Environmental Science and Technology 43, 40-83.

Lazaridis M, Latos M, Aleksandropoulou V, Hov Ø, Papayannis A, Tørseth K (2008) Contribution of forest fire emissions to atmospheric pollution in Greece. Air Quality, Atmosphere and Health 1, 143-158. doi:10.1007/S11869-008-0020-0

Lindner M, Maroschek M, Netherer S, Kremer A, Barbati A, GarciaGonzalo J, Seidl R, Delzon S, Corona P, Kolstro M, Lexer MJ, Marchetti M (2010) Climate change impacts, adaptive capacity, and vulnerability of European forest ecosystems. Forest Ecology and Management 259, 698-709. doi:10.1016/J.FORECO.2009.09.023

Penman J, Gytarsky M, Hiraishi T, Krug T, Kruger D, Pipatti R, Buendia L, Miwa K, Ngara T, Tanabe K, Wagner F (2003) ‘Good Practice Guidance for Land Use, land-Use Change and Forestry.' (Intergovernmental Panel on Climate Change (IPCC) and Institute for Global Environmental Strategies (IGES): Hayama, Japan)

Pereira JMC, Santos MTN (2003) 'Fire Risk and Burnt Area Mapping in Portugal,' (Direcção Geral das Florestas: Lisbon, Portugal)

PT NIR (2011) Portuguese National Inventory Report on Greenhouse Gases, 1990-2009. Submitted under the United Nations Framework Convention on Climate Change and the Kyoto Protocol. Amadora, April 2011. (Portuguese Environmental Agency) Available at http://unfccc.int/ files/national_reports/annex_i_ghg_inventories/national_inventories_ submissions/application/zip/prt-2011-nir-25may.zip [Verified 22 February 2013]

Rodrìguez Murillo JC (1994) The carbon budget of the Spanish forests. Biogeochemistry 25, 197-217. doi:10.1007/BF00024392

Rosa IMD, Pereira JMC, Tarantola S (2011) Atmospheric emissions from vegetation fires in Portugal (1990-2008): estimates, uncertainty analysis, and sensitivity analysis. Atmospheric Chemistry and Physics 11, 2625-2640. doi:10.5194/ACP-11-2625-2011

San-Miguel-Ayanz J, Schulte E, Schmuck G, Camia A, Strobl P, Liberta G, Giovando C, Boca R, Sedano F, Kempeneers P, McInerney D, Withmore C, Santos de Oliveira S, Rodrigues M, Durrant T, Corti P, Oehler F, Vilar L, Amatulli G (2012) Comprehensive monitoring of wildfires in Europe: the European Forest Fire Information System (EFFIS). In 'Approaches to Managing Disaster - Assessing Hazards, Emergencies and Disaster Impacts', (Ed. J Tiefenbacher) pp. 87-108, doi:10.5772/ 28441. (InTech) Available at http://www.intechopen.com/books/ approaches-to-managing-disaster-assessing-hazards-emergencies-anddisaster-impacts/comprehensive-monitoring-of-wildfires-in-europe-theeuropean-forest-fire-information-system-effis- [Verified 22 February 2013]

Schelhaas MJ, Nabuurs GJ, Schuck A (2003) Natural disturbances in the European forests in the 19th and 20th centuries. Global Change Biology 9(11), 1620-1633. doi:10.1046/J.1365-2486.2003.00684.X

Seiler W, Crutzen PJ (1980) Estimates of gross and net fluxes of carbon between the biosphere and the atmosphere from biomass burning. Climatic Change 2, 207-247. doi:10.1007/BF00137988

UNFCCC (2011). Land use, land-use change and forestry. Decision 2/ CMP.7. FCCC/KP/CMP/2011/10/Add.1 Available at http://unfccc.int/ resource/docs/2011/cmp7/eng/10a01.pdf [Verified 10 July 2012]

Xanthopoulos G, Calfapietra C, Fernandez P (2012) Fire hazard and flammability of European forest types. Managing Forest Ecosystems 24, 79-92. doi:10.1007/978-94-007-2208-8_4 